\title{
Distribution and Importance of Maize Grey Leaf Spot in West Oromia, Ethiopia
}

\author{
Midekssa Dida ${ }^{1 *} \quad$ Fikre Lemessa ${ }^{2} \quad$ Gezahegn Berecha ${ }^{2}$ \\ 1.Ethiopian Institute of Agricultural Research, Bako National Maize Research Center \\ 2. Departments of Horticulture and Plant Sciences Jimma University P.O. Box 307 Jimma, Ethiopia
}

\begin{abstract}
Maize (Zea mays) is one of the most widely cultivated crops in the world. In Ethiopia, it's a major staple food with an average productivity of $3.94 \mathrm{t} \mathrm{ha}^{-1}$, which is below the world average of 5.78 tones $\mathrm{ha}^{-1}$. A significant portion of this yield gap is attributed to biotic and abiotic stresses. Of diseases, grey leaf spot is one of the major foliar diseases threatening maize production in Ethiopia. Loss caused due to grey leaf spot reached $49.5 \%$ in Ethiopia. The objective was to assess the distribution and importance of Grey Leaf Spot. The assessments were done by sampling 81 maize fields in 9 districts from 3 zones during 2017. Purposive multistage sampling method was used. Data were analyzed using three-stage nested design. The survey result showed the highest disease prevalence $62.96 \%$ was recorded in East Wollega and the lowest $(22.22 \%)$ in West-Wollega zone. The highest mean incidence $35.06 \%$ was recorded in East Wollega whilst the lowest 9.51\% in West-Shewa. The maximum Severity index of $31.43 \%$ was in East Wollega whereas the minimum in West-Wollega (10.05\%) zones. At a district level, the highest prevalence was recorded in Leka-Dulecha followed by Gobu-Seyo with disease prevalence of $88.9 \%$ and $66.7 \%$, respectively. The highest mean incidence $48.15 \%$ was at Gobu-Seyo whereas the lowest was recorded in Gimbi 1.1\%. The highest mean severity index was in Leka-Dulecha 46.11\% whilst the lowest in Gimbi 1.78\%. Thus, there is a need to develop management strategies like crop rotation with non-host, use of tolerant varieties to reduce the impact of the disease on maize production.
\end{abstract}

Keywords: Maize disease, Incidence, Severity Index

DOI: $10.7176 / J N S R / 11-17-03$

Publication date:September $30^{\text {th }} 2020$

\section{Introduction}

Maize (Zea mays) is one of the most widely cultivated crops in the world. It is one of the three most popular cereal crops next to wheat, and rice in the world (FAOSTAT, 2016). Maize occupies an important position in world economy as a food, feed and an industrial grain crop (Tolesaet al., 1993). It serves as a vital source of proteins, calories and some of the important vitamins and minerals to billions of people worldwide, particularly in Africa, South America and Asia, and has been considered a 'poor man's nutricereal' (Prasanna et al. 2001).

Maize is grown worldwide approximately on 226.94 million hectares (ha) annually with the production of 1291.94 million metric tons (FAOSTAT, 2018). In sub-Saharan Africa, maize is produced in an estimated area of about 26 million ha with an average of 460 million metric tons. In East Africa, maize occupies about 17 million of production area and 30.4 million tons of total production and with 1.8 tons per ha (FAOSTAT, 2016).

In Ethiopia, maize is the second largest food security crop after teff, (Eragrostisteff (Zucc.) Trotter. It is primarily produced and consumed by the small-scale farmers that comprise about $80 \%$ of Ethiopia's population (Alemu et al., 2008).

Currently, about 2.13 million ha of land is covered by maize with an average production of 8.39 million tons, and the average national yield of maize is very low under small-scale farmers, which is $3.94 \mathrm{t} / \mathrm{ha}$ in the country (CSA 2018). However, it is very low as compared to the potential of maize $(8-11 \mathrm{tha}-1)$ in the high rainfall and irrigated areas and also low as compared to world average productivity 5.78 ton ha-1 (USDA-FAS 2017).

A significant portion of this yield gap is attributable to the losses caused due to biotic and abiotic stresses. The major abiotic factors include nutrient deficiency and drought stress, which could be aggravated by land degradation. Among biotic constraints, foliar diseases play a major role in contributing to the reduction of maize production and productivity across the world (Berger et al., 2014; Masuka et al., 2017).

The major diseases include Turcicum leaf blight (Exserohilum turcicum (Pass) Leonard \& Suggs), grey leaf spot (Cercospora zeae-maydis Tehon \& Daniels), leaf rust (Puccinia sorghi Schr.), maize streak virus disease (Wegary et al., 2001; Tilahun et al., 2012). A foliar disease, particularly GLS caused by Cercospora zeae-maydis (Tehon and Daniels, 1925) is one of the necrotrophic and polycyclic foliar diseases of maize that poses a serious problem to tropical maize production (Renfro and Ullstrup, 1996). This pathogen causes intense water loss from the plant thereby leading to severe blighting of the leaves and reduced photosynthesis. This eventually leads to undersized ears, low grain yield and premature death of maize plants. Severe blighting of the upper eight or nine leaves that contribute 75 to $90 \%$ of the photosynthates for grain fill may lead to stalk weakening or even infectious stalk rot diseases leading to premature stalk death and lodging (Lipps et al., 1996: Ward et al.. 1999).

In Ethiopia, a major epidemic occurred in the early 2000s and made considerable maize grain yield losses 
$36.9 \%$ and $49.5 \%$ and there have been extensively disseminated through severe outbreaks every year, particularly in the warm and humid areas of the country (Tilahun et al., 2012; Negash, 2013).

The potential threat of GLS to maize production was started and identified with a survey carried out during the year 1997-1998 to know the distribution and importance of the disease in most maize growing regions of Ethiopia (Wegary et al., 2001). The severity of grey leaf spot was high in the warm humid maize belt areas of the country adversely affecting farmers who live with limited resources. Currently, GLS, caused by Cercospora zeaemaydis, is among the major maize foliar disease in South and Southwest Ethiopia (Nega et al., 2016).

In Ethiopia, Wegaryet al. (2004) reported that yield loss due to GLS on resistant, moderately resistant and susceptible varieties was between 0-14.9\%, 13.7-18.3\%, and 20.8-36.9\% respectively during 2003/2004 cropping seasons at Bako areas. Similarly, the research carried out at South Ethiopia in the year 2004-2006 showed that the yield loss due to GLS is $29.5 \%$ (Tilahun et al., 2012).

The survey study showed that the highest GLS prevalence, incidence and severity were $74 \%, 71.2 \%$ and $45.13 \%$ respectively in South and Southwest Ethiopia. Similarly, morphological characterization of GLS isolates were carried out and 10 different isolates were identified (Nega et al., 2016). Therefore, this study showed the importance of the pathogen distribution and diversity of the isolates in the country. Even though Western Oromia is a potential to produce maize crop, importance of the pathogen is not assessed and determined to take a measure.

Studies have been conducted on major foliar diseases of maize since late 1990's in the western part of the country (Wegary et al., 2001). However, it was little indicated specifically for GLS and no updated information on the distribution and disease intensity, on its distribution map in the study area. Therefore, the objective of this study was to assess the distribution and importance of maize Grey leaf spot in West Oromia, Ethiopia.

\section{MATERIALS AND METHODS \\ Survey of Grey Leaf Spot of Maize \\ Description of the Survey Area}

The survey covered the most important maize growing zones of West-Shewa, East Wollega and West-Wollega Zone of Oromia Regional administration which covered 9 districts namely Dano Ilu-Gelan, Bako-Tibe, GobuSeyo, Sibu-Sire, Leka-Dulecha, Gimbi, Lalo-Asabi, Ayra-Guliso and a total of 27 Kebeles each district having 3 Kebeles.

\section{Sampling and Sampling Techniques}

Purposive multistage sampling method was used to reach the Kebeles. Potential districts were selected with in collaboration with Zonal experts, whereas particular Kebeles were selected with experts from each district based on the potential to produce maize crop and accessibility. Maize fields were selected through random sampling technique with frequent stopping at 3-5 km intervals depending on the variability of fields in terms of altitude and cropping systems (Kinyua et al., 2010). The survey route followed major roads and accessible roadside to towns and localities in each zone and district across different altitude. Five representative maize leaf samples with symptoms recognized as those of GLS (principally, pale brown or grey to tan, long narrow streaks that become dark, grayish-brown rectangular lesions as the disease develops) per field were collected along the survey routes. A total of 81 fields were assessed from 27 Kebeles 3 farms from each Kebeles during main cropping season of 2017 when the crop is dough stage.

Samples were air dried and kept in a pressing board after covered with newspaper in the form of the herbarium. Information like Zone, district, Kebeles, sample code, farm number, name of the collector, date of collection, were written on the label paper and attached to the margin of folded newspaper used to cover the leaves sample (Lyimo et al., 2013). Samples were transported to Jimma University Plant Pathology Laboratory and kept in a refrigerator at $4^{\circ} \mathrm{C}$ for further isolation and identification.

\section{Disease Assessment}

For the assessment of disease incidence and severity, the fields were selected randomly, and the incidence and severity of GLS on maize plants were assessed. A total of 30 plants per field were assessed by visual scale moving in "W" pattern in the field (Cardwell et al., 1997). Severity of GLS on maize leaf was assessed by using a 1-5 visual disease rating scales in all fields, where: 1 = no symptoms (Very slight to slight infection, one or two to few Scattered lesions on lower leaves); 2 = moderate lesion development below the leaf subtending the ear; $3=$ heavy lesion development on and below the leaf subtending the ear with a few leaves, $4=$ severe lesion development on all but the uppermost leaves, which may have a few lesions; and 5 = all leaves dead (Maroof et al., 1993).

\section{Data Collection}

Disease Incidence

During the field survey, incidences, visual scale of severity, information of the field such as GPS readings (Altitude, Latitude, and Longitude) were recorded. Additionally, farming practices, maize varieties, previous cropping 
history, like were recorded through visual observation and by interviewing the farmers.

Disease incidence was computed as a percentage of infected maize plants out of total maize plants in the sample plot shown as follow:

$$
\text { Disease Incidence }(\%)=\frac{\text { Number of diseased plants }}{\text { Total Number of Plants inspected }} \mathrm{X} 100
$$

\section{Disease Severity}

During field survey, data on disease severity were recorded by evaluating the field using 1-5 disease recording scale in all assessed fields of the districts.

The numerical rating was converted to percentage severity index (PSI) using the following equation suggested by Wheeler (1969).

$$
\text { PSI }=\frac{\text { Sum of all Numerical rating }}{\text { Total Number of rated plants X Maximum disease score on scale }} \text { X100 }
$$

\section{Disease Prevalence}

The prevalence of the disease was measured by using the number of fields affected divided by a total number of fields assessed and expressed in percentage:

$$
\text { Disease Prevalence }(\%)=\frac{\text { Number of infected fields }}{\text { Total number of fields assessed }} \times 100
$$

\section{Data analysis}

The survey data on incidence and severity index of GLS were analyzed using three-stage nested design by nesting districts in Zone, Kebeles within districts and farms within Kebeles with the following model to see their interaction.

$$
y_{i j k}=\mu+\tau_{i}+\beta_{j(i)}+\gamma_{k(i j)}+\varepsilon_{l(i j k)}
$$

Where: $y_{i j k}$ is the GLS disease intensity where Kebeles $k$ is nested within district $J$ nested within zone $i$, $\mu$ is the overall mean, $\tau_{i}$ is the effect of the $i^{t h}$ zone, $\beta_{j(i)}$ is the effect of the $j^{t h}$ district within the $i^{t h}$ zone, and $\gamma_{k(i j)}$ is the effect of the $k^{\text {th }}$ Kebeles within the $j^{\text {th }}$ district and $i^{\text {th }}$ zone, and $\varepsilon_{l(i j k)}$ is the error term.

Analysis of variance (ANOVA) was performed using SAS V 9.3statistical (SAS 2010). Means were separated using LSD t-test at significance levels of 0.05 . The associations of GLS disease incidence and severity with altitude, maize variety, and previous crop were computed using Pearson correlation analysis. In addition, the current extent and the distribution of Grey leaf spot across West Oromia region were mapped by using Arc GIS software 10.1 from the collected GPS coordinates.

\section{RESULTS AND DISCUSSION}

Disease Intensity, Distribution of Maize GLS and effect of different variables

Disease Intensity and prevalence of GLS at Zone level

The study revealed that Grey leaf spot disease was found in all assessed zones of Western-Oromia. Statistically, there was highly significant $(\mathrm{p}<0.001)$ difference among districts in terms of maize grey leaf spot incidence and severity. Grey Leaf spot of maize was observed with an incidence ranging from $0-76.67 \%$ in West-Shewa zone, 0-80\% in East Wollega zone, and $0-70 \%$ in West-Wollega zone. The highest mean incidence of Grey leaf spot disease was recorded in East Wollega zone (35.06 \%) followed by West-Shewa zone (12.09\%). The minimum mean incidence was observed in West Wollega zone with 9.51\%. Disease Severity index of Grey leaf spot was observed to be in the range $(0-72 \%)$ in west Showa zone, whilst $(0-79.67 \%)$ in East Wollega and $(0-74.84 \%)$ in West Wollega zone. The highest mean severity index $(31.43 \%)$ was recorded in East Wollega Zone followed by West Showa zone having $11.98 \%$ severity, whereas the minimum severity index was recorded in West Wollega zone with $10.05 \%$ (Table 1).

Grey Leaf Spot disease prevalence across Zones showed significant differences with the highest value in East Wollega Zone with $62.96 \%$ followed by West-Shewa Zone with $29.63 \%$ disease prevalence while the lowest was recorded in West Wollega Zone with $22.22 \%$ of GLS disease prevalence (Table 1).

Table 1.Mean disease Incidence and Severity of GLS of maize across study zones in 2017

\begin{tabular}{llll}
\hline Zone & Prevalence $(\%)$ & Mean Incidence & Mean Severity \\
\hline West Showa & 29.63 & $12.09^{\mathrm{b}}$ & $11.98^{\mathrm{b}}$ \\
East Wollega & 62.96 & $35.06^{\mathrm{a}}$ & $31.43^{\mathrm{a}}$ \\
West Wollega & 22.22 & $9.51^{\mathrm{b}}$ & $10.05^{\mathrm{b}}$ \\
\hline LSD & & 3.41 & 1.67 \\
CV $(\%)$ & & 75.4 & 64.39 \\
\hline
\end{tabular}

$\mathrm{LSD}=$ Least significance difference

Figures followed by the same letter are not significantly different at 0.05 . 


\section{Disease Prevalence and Intensity at district level}

The highest GLS disease prevalence of $88.9 \%$ was found in Leka-Dulecha district followed by Gobu-Seyo district with $66.7 \%$ prevalence. Also, the medium prevalence were recorded in Dano, Sibu-Sire, and Lalo-Asabi with $44.44 \%, 33.33 \%$, and $33.33 \%$, respectively. On the other hand, less GLS prevalence was recorded in Ilu-Gelan, Gimbi, Ayra-Guliso, and Bako-Tibe districts respectively having 22.2\%, 22.2\%, 22.2\%, and 11\%. (Table 2). The variation in the disease prevalence among the districts is due to the variation in agro-ecology. For instance, LekaDulecha had the highest altitude range which ranges from (2031-2422 m.a.s.l) which associated with high rainfall and also farming practices enhanced the disease. Other things kept constant, the use of specific maize variety had its own effect as disease prevalence is minimum with shone and Limu maize varieties as compared to others.

The prevalence of high incidence of grey leaf spot in cool humid high-altitude areas had also been reported (Lipps 1995; Asea et al. 2005). Incidence ranges of GLS in maize fields were varied from 0-50\%, 0-60\% and 076.7\% in Dano, Ilu-Gelan, and Bako-Tibe districts of West-Shewa zone, respectively. Similarly, Gobu-Seyo, SibuSire and Leka-Dulecha districts of East-Wollega zone had shown incidences that range from 0-80\%, 0-46.7\% and 0-73.3\%, respectively. Also, districts of West-Wollega zone namely Gimbi, Lalo-Asabi, and Ayra-Guliso had an incidence ranging from $0-6.7 \%, 0-40 \%$ and $0-70 \%$, respectively (Table 2 ).

Moreover, the highest mean incidence of GLS in West-Shewa zone was recorded at Ilu-Gelan with $15.2 \%$, followed by Dano (10.74\%), whereas the smallest mean incidence was recorded in Bako-Tibe district with $10.37 \%$. In East-Wollega zone, Gobu-Seyo district had the highest mean incidence of $48.15 \%$, followed by Leka-Dulecha district with $47.77 \%$, whereas the minimum mean incidence was recorded in Sibu-Sire district with 9.26\%. Similarly, in West-Wollega, the highest mean incidence of $17.41 \%$ was recorded in Ayra-Guliso followed by LaloAsabi (10\%), but the minimum mean incidence of $1.11 \%$ was found in Gimbi district (Table 2). The difference in disease intensity and prevalence among zones and districts could be due to the differences in environmental factors (altitude, temperature, humidity), and farming practices at the study area.

Those districts with comparatively high disease incidence and severity index were practicing monoculture under high relative humidity. For instance, in Leka-Dulecha and Gobu-Seyo the farmers were mainly practicing using BH660 maize variety which is relatively with high disease intensity. On the other hand, in Ilu-Gelan and Bako-Tibe farmers were mainly practicing using Shone and Limu maize varieties. De Nazareno et al., (1993) also reported that when the weather conditions were favorable for the development of the disease, there was a significant positive relationship between the relative humidity and disease severity.

Disease Severity index of Grey leaf spot was observed with a range of $0-72 \%$ in West-Shewa zone, 0-79.67\% in East-Wollega and 0-74.84\% in West-Wollega zone. The highest mean severity index was recorded in EastWollega zone with $31.43 \%$ followed by West-Shewa zone having $11.98 \%$, whereas the minimum severity index was recorded in West-Wollega zone with $10.05 \%$ (Table 2). The range of disease Severity of Grey Leaf Spot of Maize was varied from $0-65 \%, 0-57.5 \%, 0-72.8 \%$ in Dano, Ilu-Gelan and Bako-Tibe districts of West-Shewa zone, respectively, whereas in Gobu-Seyo, Sibu-Sire, and Leka-Dulecha of East-Wollega zone it varied from 0$79.7 \%, 0-48.3 \%$, and 0-74.8\%, respectively. Similarly, in West-Wollega zone, Gimbi, Lalo-Asabi, andAyraGuliso districts disease severity ranges from $0-8 \%, 0-48 \%$ and $0-74.9 \%$, respectively (Table 2 ).

The highest mean disease severity of Grey Leaf Spot in West-Shewa zone was recorded at Dano with $16.33 \%$ value followed by Ilu-Gelan with $12.00 \%$ whereas the smallest mean incidence was recorded in Bako-Tibe district with 7.59\%. In East-Wollega zone Leka-Dulecha district the mean GLS disease severity was the highest with $46.11 \%$ followed by Gobu-Seyo with mean severity value of $39.15 \%$, whereas the minimum disease severity was recorded in Sibu-Sire district with $9.37 \%$.

Similarly, the highest mean severity index in West-Wollega zone was recorded in Ayra-Guliso with 16.68\% followed by Lalo-Asabi with $11.75 \%$ whereas severity the minimum value in Gimbi district with $1.78 \%$ (Table 2). Also percent of disease severity index of the districts were showed on (Figure 1) with their respective level. Accordingly, Leka-Dulecha and Gobu-Seyo districts were grouped under high severity index, whereas Dano, IluGelan, Lalo-Asabi and Ayra-Guliso were under moderate severity index. On the other hand, Bako-Tibe, Sibu-Sire and Gimbi districts were under lower disease severity index (Figure. 1).

Those districts with maximum disease incidence and severity index had relatively high relative humidity, less crop rotation, and use of susceptible maize varieties as compared to those districts recorded with the minimum. Results from various surveys conducted in most maize growing regions of Ethiopia indicated that the disease has a wide distribution and significant impact on maize yield reduction on both local and improved susceptible varieties (Tadesse, 2008). Survey of maize diseases in Western and Northwestern Ethiopia by Tefferi (1999) showed that disease incidence and severity were relatively high. Similarly, in the U.S.A. (Iowa), the epidemic of grey leaf spot is severe under monoculture maize with no rotation practices and minimum tillage practices (Perkins et al., 1995).

All of the surveyed districts had shown severity ranges from mild to moderately severe grey leaf spot infection indicating the potential of the disease in hindering maize productivity. Agro-ecology of the assessed areas was conducive to the current disease prevalence and intensity. Comparatively warm temperature and high rainfall could 
give rise to high relative humidity which results in a conducive environment for the pathogen epidemic and enhance disease intensity. In Leka-Dullecha and Gobu-Seyo where the relative humidity is relatively high, disease incidence and severity index were showed high. Reportedly, warm temperature, well-distributed rainfall, and high relative humidity are weather conditions favoring this disease development (Beckman and Payne 1983).

Table 2. Disease Prevalence, incidence and Severity index of Grey Leaf spot across the study area in 2017

\begin{tabular}{lcccccc}
\hline Districts & Altitude Range & Prevalence & \multicolumn{2}{c}{ D I (\%) } & \multicolumn{2}{c}{ SI $(\%)$} \\
\cline { 3 - 6 } & & $(\%)$ & Range & Mean & Range & Mean \\
\hline Dano & $1630-2131$ & 44.44 & $0-50$ & $10.74^{\text {cd }}$ & $0-65.0$ & $16.33^{\text {cd }}$ \\
Ilu-Gelan & $1685-1923$ & 22.22 & $0-60$ & $15.19^{\text {bc }}$ & $0-57.5$ & $12.00^{\text {cde }}$ \\
Bako-Tibe & $1657-1900$ & 11.11 & $0-76.7$ & $10.37^{\text {cd }}$ & $0-72.8$ & $7.59^{\mathrm{e}}$ \\
Gobu-Seyo & $1646-1959$ & 66.67 & $0-80$ & $48.15^{\mathrm{a}}$ & $0-79.7$ & $39.15^{\mathrm{b}}$ \\
Sibu-Sire & $1668-1983$ & 33.33 & $0-46.7$ & $9.26^{\mathrm{d}}$ & $0-48.3$ & $9.37^{\mathrm{e}}$ \\
Leka-Dulecha & $2031-2422$ & 88.89 & $0-73.3$ & $47.77^{\mathrm{a}}$ & $0-74.8$ & $46.11^{\mathrm{a}}$ \\
Gimbi & $1846-1920$ & 22.22 & $0-6.7$ & $1.11^{\mathrm{e}}$ & $0-8.00$ & $1.78^{\mathrm{e}}$ \\
Lalo-Asabi & $1550-1852$ & 33.33 & $0-40$ & $10.00^{\mathrm{cd}}$ & $0-48.0$ & $11.70^{\mathrm{de}}$ \\
Ayra-Guliso & $1543-1631$ & 22.22 & $0-70$ & $17.41^{\mathrm{b}}$ & $0-74.9$ & $16.68^{\mathrm{c}}$ \\
\hline LSD (0.05) & & & & 5.91 & & 4.76 \\
CV & & & & 74.43 & & 64.39 \\
\hline
\end{tabular}

LSD=Least significant difference $\quad \mathrm{DI}=$ disease incidence $\quad \mathrm{SI}=$ severity index $\mathrm{CV}=$ coefficient of variance
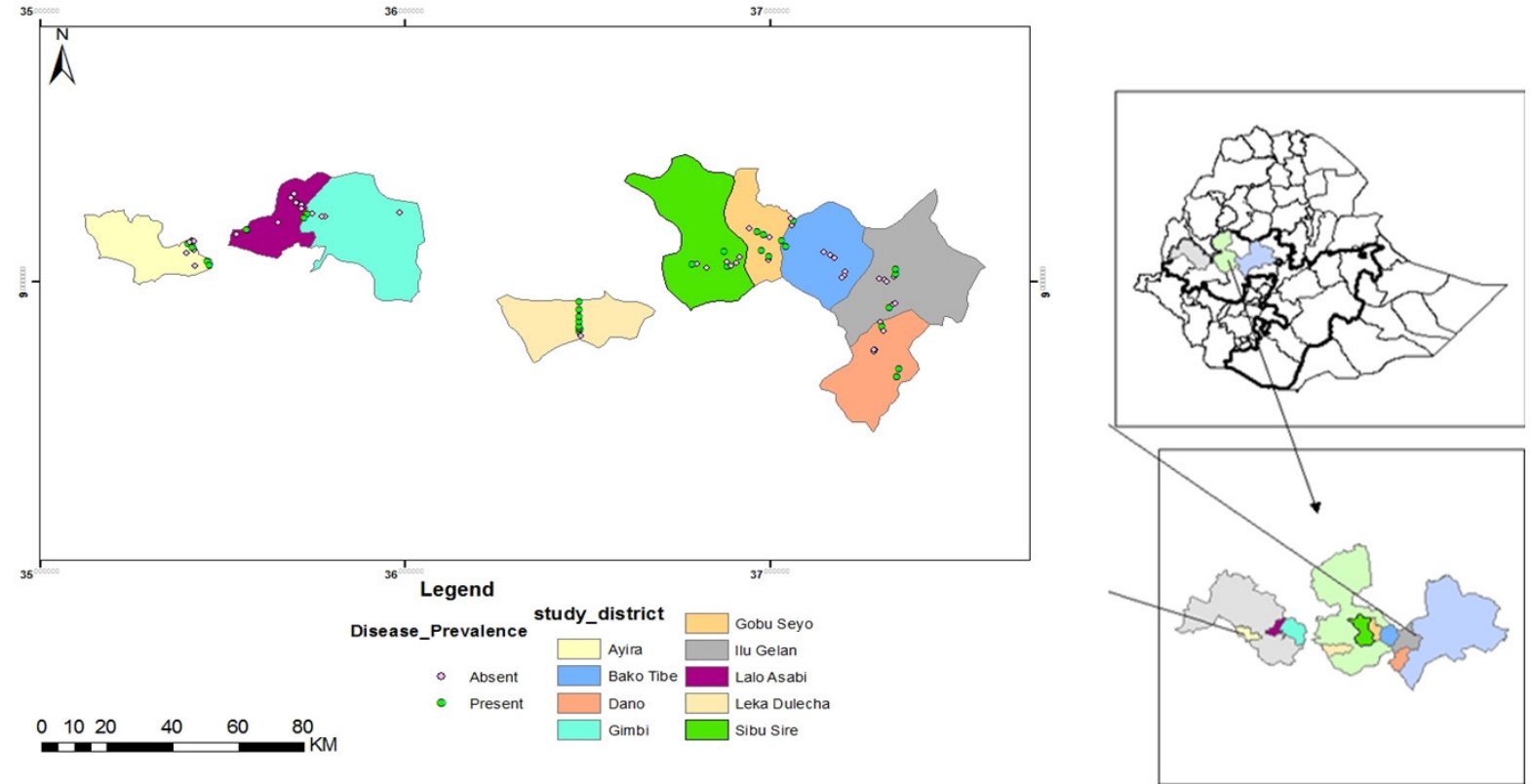

Fig: 1 GLS distribution across districts in zones

\section{Effects of different practices on disease incidence and severity of GLS \\ Effect of Farming Practices}

The highest disease incidence and severity index was recorded on monoculture farming practices with $35.00 \%$ and $47.50 \%$, respectively, followed by intercropping having $20.80 \%$ and $21.26 \%$ respectively. The disease incidence and severity index was nil in fallow farming practice (Table 3). The increase in disease intensity on monoculture practice was due to the high inoculums developed in the field year after year whereas the decrease of the disease intensity in the rotation and fallow practices were due to maize is the only host crop this fungus is known to attack. Grey leaf spot of maize is known to be pathogenic only to maize; rotation of the non-host crop for two years can reduce the disease inoculums effectively (Latterell and Rossi, 1983). Cropping methods such as mono or intercropping and use of cultivar mixture are also recognized to supply to disease pressure in positive or negative ways (Agrios, 2005). Intercropping practices also showed the highest disease incidence and severity index next to monoculture (Table 3). Similarly, mixed or intercropping also important in disease intensity because it hinders air circulation inside the crop field which helps to increase relative humidity and favors disease development (Wolf, 2002; Dhami, 2015). 
Table 3. Mean of disease incidence and severity index across farming practices data from the survey during 2017

\begin{tabular}{llll}
\hline Variable & Class & Incidence (\%) & Severity Index (\%) \\
\hline \multirow{3}{*}{ Farming Practice } & Monoculture & $35.00^{\mathrm{a}}$ & $47.50^{\mathrm{a}}$ \\
& Intercrop & $20.80^{\mathrm{ab}}$ & $21.26^{\mathrm{b}}$ \\
& Rotation & $11.33^{\mathrm{b}}$ & $12.36^{\mathrm{b}}$ \\
& fallow & $0.00^{\mathrm{b}}$ & $0.00^{\mathrm{b}}$ \\
\hline & LSD & 22.05 & 21.76 \\
\hline
\end{tabular}

LSD=Least significant difference Figures followed by the same letter are not significantly different

\subsubsection{Effect of Maize Varieties}

During the assessment, there were about nine hybrids and one local maize variety grown over the surveyed districts. Accordingly, Limu variety had the highest coverage with $35.80 \%$ followed by BH660 variety having $30.86 \%$ of the total assessed farms. Shone and BH661 with 14.81\% and 9.88\% had the medium coverage, whereas BH140, BH543, BH545, BH546 and Local maize varieties with $1.23 \%$ each, had the minimum coverage under the surveyed districts (Table 4). The highest disease incidence and severity index was recorded on BH545 (70\% and 79.67\%), BH546 (80\% and 68\%), BH540 (63.33\% and 61.07\%), BH140 (76.67\% and 73.67\%) and local maize varieties with (70 and $74.87 \%$ ), respectively. On the other, the minimum disease incidence and severity index were recorded on Limu with (2.29\% and 2.77\%), respectively (Table 4). This result implies that there is a great variation among maize varieties in reaction to the pathogen which could be due to genetic variation within varieties. Increased incidence of GLS has been associated with the continuous cultivation of maize, and use of susceptible maize cultivars (Gevers 1994; De Nazareno et al., 1993; Wegary et al., 2008). The responses of some commercial varieties were showed different resistance and susceptibility level among different maize hybrids (Wegary et al., 2004; Ward et al., 1996). Similarly, according to field survey report, Tefferi (1999) of all released hybrid maize, only BH-660, and PHB-30H83 were found relatively tolerant to grey leaf spot.

Table 4. Mean of DI and DSI of GLS across assessed maize varieties.

\begin{tabular}{lccc}
\hline Maize Variety & Farm $(\%)^{\mathrm{a}}$ & DI $(\%)$ & DSI $(\%)$ \\
\hline Limu & 35.80 & $2.29^{\mathrm{d}}$ & $2.77^{\mathrm{d}}$ \\
BH660 & 30.86 & $26.67^{\mathrm{cb}}$ & $27.52^{\mathrm{bc}}$ \\
Shone & 14.81 & $10.30^{\mathrm{cd}}$ & $10.12^{\mathrm{cd}}$ \\
BH661 & 9.88 & $13.75^{\mathrm{cbd}}$ & $19.13^{\mathrm{cd}}$ \\
BH540 & 2.47 & $63.33^{\mathrm{a}}$ & $61.07^{\mathrm{a}}$ \\
BH543 & 1.23 & $33.33^{\mathrm{b}}$ & $39.33^{\mathrm{b}}$ \\
BH545 & 1.23 & $70.00^{\mathrm{a}}$ & $79.67^{\mathrm{a}}$ \\
BH546 & 1.23 & $80.00^{\mathrm{a}}$ & $68.00^{\mathrm{a}}$ \\
BH140 & 1.23 & $76.67^{\mathrm{a}}$ & $73.67^{\mathrm{a}}$ \\
Local & 1.23 & $70.00^{\mathrm{a}}$ & $74.87^{\mathrm{a}}$ \\
\hline LSD (0.05) & & 19.9 & 20
\end{tabular}

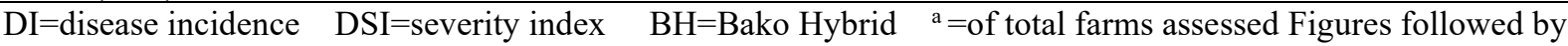
the same letter are not significantly different at 0.05 .

\section{Effect of Previous crop history}

In surveyed districts majority of the farmers (51.85\%) grow maize after maize and $14.81 \%$ grow maize after pepper and $12.35 \%$ grow maize after teff whereas $4.94 \%$ and $3.70 \%$ of the farmers grow sorghum and Common bean, respectively. Similarly, Noug and fallow, each had (2.40\%) whereas potato and wheat, $(4.92 \% \& 2.63 \%)$ in the previous cropping history. The highest disease incidence and severity index was recorded on rotation maize after maize cropping history with (40\% and $45.4 \%)$ whilst the minimum incidence and severity index were recorded on maize grown after potato, Noug, and fallow each account $0 \%$ (Table 5).

The highest result in disease intensity on rotating maize after maize could be due to increase in the amount of inoculum in the field year after year, whereas growing maize after non-host crops to GLS, like Potato, Noug and fallow were showed the lowest disease intensity. On some of the non-host crops like pepper and C. bean GLS incidence and severity were shown high in relation to fallow and Noug. This implies that the pathogen may over winter in maize residue if not properly removed and decomposed. Therefore, it is better to completely remove maize residue and/or deep ploughed to improve the decomposition residue effectively.

Increased incidence of GLS in Africa has been associated with cultural practices such as reduced tillage, continuous cultivation of maize, and use of susceptible maize cultivars (Gevers 1994). Smith, (1989); Ward, (1996) also reported the deficiency of mineral nutrients required by the pathogen may have a potential role in GLS epidemics. Similarly, maize is the only host crop this fungus is known to attack, therefore, rotation with non-host crop Soybean and potato can reduce the disease inoculums effectively (Lipps, 1998; Wolf, 2002; Dhami, 2015). 
Table 5. Mean of disease incidence and severity index of GLS across assessed previous crop varieties at study area in 2017

\begin{tabular}{|c|c|c|c|c|}
\hline Variables & Class & $\%$ of Farms & Incidence (\%) & Severity index (\%) \\
\hline \multirow{10}{*}{ Previous Crop ${ }^{a}$} & Maize & 51.85 & $40.00^{\mathrm{a}}$ & $45.00^{\mathrm{a}}$ \\
\hline & Teff & 12.35 & $16.67^{\mathrm{ab}}$ & $20.76^{\mathrm{ab}}$ \\
\hline & Pepper & 14.81 & $19.74^{\mathrm{ab}}$ & $17.19^{\mathrm{b}}$ \\
\hline & Sorghum & 4.94 & $24.44^{\mathrm{ab}}$ & $24.93^{\mathrm{ab}}$ \\
\hline & C. bean & 3.70 & $18.00^{\mathrm{ab}}$ & $22.87^{\mathrm{ab}}$ \\
\hline & Potato & 4.92 & $0.00^{\mathrm{b}}$ & $0.00^{\mathrm{b}}$ \\
\hline & Fallow & 2.40 & $0.00^{\mathrm{b}}$ & $0.00^{\mathrm{b}}$ \\
\hline & Noug & 2.40 & $0.00^{\mathrm{b}}$ & $0.00^{\mathrm{b}}$ \\
\hline & Wheat & 2.63 & $17.62^{\mathrm{ab}}$ & $18.53^{\mathrm{ab}}$ \\
\hline & LSD & & 27.37 & 26.96 \\
\hline
\end{tabular}
letter are not significantly different at 0.05 .

\section{Effect of Altitude}

The result from the altitude of the survey area revealed that comparatively the highest disease incidence and disease severity index was recorded at high altitude ranges from 2301-2422 m.a.s.l with $40.00 \%$ and $46.30 \%$, respectively. The lowest disease incidence and severity index was recorded at the mid-altitude ranges from 1543-2300 m.a.s.1 having $12.8 \%$ for both respectively (Table 6). This result implies that the pathogen is more severe on the higher altitude might be due to the higher relative humidity associated with a higheraltitude than with the mid-latitudes of the study area. The prevalence of high incidence of grey leaf spot in cool humid high-altitude areas has also been reported by Lipps (1995), whereas the results by Lyimo et al. (2013) have shown increasing severity of grey leaf spot in low-altitude warmer areas. Therefore, altitude association with other environmental factors like relative humidity and temperature has its own effect in increasing or decreasing disease intensity.

Table 6. Mean disease incidence and severity index of GLS across the agro-ecology of assessed areas in 2017.

\begin{tabular}{llll}
\hline Variable & Class & Incidence $(\%)$ & Severity Index $(\%)$ \\
\hline Altitude & $1543-2300$ & $12.85^{\mathrm{b}}$ & $12.87^{\mathrm{b}}$ \\
& $2301-2422$ & $40.00^{\mathrm{a}}$ & $46.30^{\mathrm{a}}$ \\
\hline & LSD $(0.05)$ & 10.36 & 10.21 \\
\hline
\end{tabular}

$\mathrm{LSD}=$ Least significance difference

\section{The Relationship between Altitude, Variety and GLS Intensity}

Pearson correlation analysis indicated that there is highly significant $(\mathrm{P}<0.01)$ and strong direct relationship between disease incidence and severity index $(\mathrm{r}=0.98)$, Altitude $(\mathrm{r}=0.38)$ and maize varieties $(\mathrm{r}=0.58)$. Similarly, disease severity index with altitude $(\mathrm{r}=0.46)$ and maize varieties $(\mathrm{r}=0.58)$ had a significant positive and strong correlation (Table.7).

This result indicates that some variables like altitude have a strong correlation with disease incidence and severity index this is due to factors associated with altitude like high rainfall could give rise to high relative humidity which results in high disease intensity. Similarly, warm temperature, well-distributed rainfall, and high relative humidity are weather conditions favoring this disease development (Wheeler, 1969).

Table 7. Pearson correlation association between variety, altitude, GLS incidence, and severity

\begin{tabular}{lccc}
\hline & Severity. & Altitude. & Maize variety \\
\hline Incidence & $0.98^{* *}$ & $0.38^{* *}$ & $0.58^{* *}$ \\
Severity & & $0.46^{* *}$ & $0.58^{* *}$ \\
Altitude & & $0.06^{\mathrm{ns}}$ \\
Maize Variety & & \\
\hline $\mathrm{ns}=$ non-significant, ${ }^{* *}$ highly significant $\mathrm{p}<0.01$ & &
\end{tabular}

\section{CONCLUSION}

Survey result showed that Grey Leaf spot distributed in most of the surveyed Zones and districts, with a significant variation in incidence and severity index from district to district. Accordingly, the highest disease incidence and severity index was recorded in East Wollega zone followed by West Showa zone. The reason for the variation in incidence and severity among zones and districts could be due to the variation in altitude and other factors related to altitude during the survey season. From the survey result, the farmers at relatively high disease prevalence and intensity area shall better use those maize varieties with less severity and practicing crop rotation to minimize disease intensity. Besides, there is a need to develop effective, affordable and sustainable management strategies 
to reduce the effect of GLS on maize production in the study area. Further study would be required in order to see the trend of disease distribution and importance of maize grey leaf spot disease over seasons, as this study only considered one season data.

\section{ACKNOWLEDGEMENT}

The authors would like to thank Ethiopian Institute of Agricultural Researches for financial support provided to conduct the work. We are also grateful to Jimma University College of Agriculture and veterinary medicine for hosting.

\section{REFERENCES}

Agrios GN (2005) Plant Pathology. 5th Edition, Academic Press, New York, USA p: 952.

Asea G, Lipps PE, Pratt RC, Gordon SG, Adipala E. 2005. Development of Greenhouse Inoculation Procedures for Evaluation of Partial Resistance to Cercospora zeae-maydis in Maize Inbreds. Journal of Phytopathology $153,647-653$

Beckman, P.M. \& Payne, G.A. 1983.Cultural techniques and conditions influencing growth and sporulation of Cercosporazeae-maydis and lesion development in corn. Phytopathology 73, 286-289

Berger, K, Maryke C, Jeanne N, Felix M, Frederik J, Pangirayi T, and Alexander A . 2014. Mapping QTL conferring resistance in maize to grey leaf spot disease caused by CercosporaZeina. BMC Genetics, 15:60.

Cardwell, K.F., Schulthess, F., Ndemah, R. and Ngoko, Z., 1997.A systems approach to assess crop health and maize yield losses due to pests and diseases in Cameroon.Agriculture, ecosystems \& environment, 65(1), pp.33-47.

CSA (Central Statistic Authority). 2018. Report on area and production of crops: Agricultural sample survey on private peasant holdings of 2017/2018 Meher season. Central Statistic Authority, Addis Ababa, Ethiopia.

Alemu, D., Mwangi, W.M., Nigussie, M. and Spielman, D.J., 2008. The maize seed system in Ethiopia: challenges and opportunities in drought-prone areas.

De Nazareno, N.R.X., Lipps, P.E. and Madden, L.V., 1993. Effect of levels of corn residue on the epidemiology of gray leaf spot of corn in Ohio.Plant Disease, 77(1), pp.67-70.

Dhami, N.B., 2015. A review on the threat of grey leaf spot disease of maize in Asia. , 1, pp.71-85.

FAOSTAT (Food and Agriculture Organization). 2016. Statistical Database of the Food and agriculture.

FAOSTAT (Food and Agriculture Organization). 2018. Statistical Database of the Food and agriculture

Gevers, J.K., 1994. GLSI-A major gene for resistance to grey leaf spot in maize.South African Journal of Science, 90(7), pp.377-380.

Kinyua ZM, Smith JJ, Kibata GN, Simons SA, Langat BC. 2010. Status of grey leaf spot disease in Kenyan maize production ecosystems. African Crop Science Journal, Volume 18, No. 4, pp. 183-194.

Latterell, F.M. \& Rossi, A.E. 1983. Grey leaf spot of corn: A disease on the move. Plant Disease 67, 842-847.

Lipps, P.E. (1995). Gray leaf spot of corn.Pages 37-44 in: Proc. 7th.Annu. Iowa State Univ. Integr. Crop Manage. Conf. Ames.

Lipps, P.E., Thompson, P.R., \& Pratt, R.C. 1996. Reaction of corn hybrids to grey leaf spot. Pages 163-189 In: Rep. Annual. Corn Sorghum Res. Conf., $51^{\text {st }}$

Lipps, P.E., 1998. Grey leaf spot: A global threat to corn production. APSnet Feature (May). Published online by The American Phytopathological Society, St. Paul, MN.

Lyimo, H.J.F., Pratt, R.C. and Mnyuku, R.S., 2013. Infection Process in Resistant and Susceptible Maize (Zea mays L.)Genotypes to Cercosporazeae-maydis (Type II).Plant Protection Science, 49(1).

Maroof S, Van MA, Scoyoc SW, and Yu YG (1993) Grey leaf spot disease of maize: Rating methodology and inbred line evaluation. Plant Disease 77: 583-587

Masuka, B., G.N. Atlin, M. Olsen, C. Magorokosho, M. Labuschagne, J. Crossaet al. 2017. Gains in maize genetic improvement in eastern and southern Africa: I. CIMMYT hybrid breeding pipeline. Crop Science. 57:1-12.

Nega A, Lemessa F, Berecha G 2016 Distribution and Importance of Maize Grey Leaf Spot (Cercosporazeaemaydis) (Tehon and Daniels) in South and Southwest Ethiopia. J Plant Pathology \&Microbiology 7: 362.

Negash, M., 2013.Effect of Foliar Fungicide, Tillage and Variety on Maize Gray Leaf Spot (Cercosporazeaemaydis) at Bako, Ethiopia.Ethiopian Journal of Applied Science and Technology. 4(2): 65-84.

Perkins, J.M., Smith, D.R., Kinsey, J.G. and Dowden, D.C., 1995, March. Prevalence and control of gray leaf spot.In Proc. Annual.Conf. Ill. Maize Breeders School (Vol. 31, pp. 177-185).

Prasanna B, Vasal S, Kasahun B, Singh N.N. 2001. Quality protein maize.Curr. Sci. 81: 1308-1319.

Renfro, B.L. and Ullstrup, A.J. 1996. Comparison of maize disease in temperate and tropical environments. PANS 22: 491-498.

SAS, S. and Guide, S.U.S., 2010. SAS Institute Inc. Cary, NC, USA.

Smith, K.L. 1989. Epidemiology of grey leaf spot of field corn (Zea-mays L.) caused by CercosporazeaemaydisTehon and Daniels. Ph.D. Thesis, University of Maryland, USA 
Tadesse A (ed.) 2008 Increasing Crop Production through Improved Plant Protection Volume I. Plant Protection Society of Ethiopia (PPSE), 19-22 December 2006. Addis Ababa, Ethiopia. PPSE and EIAR, Addis Ababa, Ethiopia p: 598.

Tefferi, A., 1999. Survey of maize diseases in Western and Northwestern Ethiopia. Maize Production Technology for the Future: Challenges and Opportunities. Proceedings of the Eastern and Southern Africa Regional Maize Conference, 6; Addis Ababa (Ethiopia); 21-25 Sep 1998. In Maize Production Technology for the Future: Challenges and Opportunities. Proceedings of the Eastern and Southern Africa Regional Maize Conference, 6; Addis Ababa (Ethiopia); 21-25 Sep 1998 CIMMYT Addis Ababa (Ethiopia) BCIMMYT EARO^ C1999 (No. 633.15 EAS No. 6. CIMMYT.). Centro Internacional de Mejoramiento de Maiz y Trigo (CIMMYT), Mexico DF (Mexico).

Tehon, L.R., and Daniels, E., 1925. Notes on the parasitic fungi of Illinois: II. Mycologia, 17(6), pp.240-249.

Tilahun, T., Wagary, D., Demissie, G., Negash, M., Admassu, S. and Jifar, H., 2012. Maize pathology research in Ethiopia in the 2000s: A review. In Meeting the Challenges of Global Climate Change and Food Security through Innovative Maize Research (p. 193).

Tolesa, B., Gobezayehu, T., Worku, M., Desalegne, Y., Mulatu, K. and Bogale, G., 1993. Genetic improvement of maize in Ethiopia: A review. In 1. National Maize Workshop of Ethiopia, Addis Abeba (Ethiopia), 5-7 May 1992. IAR.

USDA-FAS, (2017).United States Department of Agriculture, Foreign Agricultural Service. World Agricultural Production Circular Series WAP04 -17, April 2017.

Ward, J.M.J. 1996. Epidemiology and management of grey leaf spot: A new disease of maize in South Africa. Ph.D. Thesis. University of Natal, Pietermaritzburg 3200, South Africa.

Ward, J.M., Stromberg, E.L., Nowell, D.C. and Nutter Jr, F.W., 1999. Gray leaf spot: a disease of global importance in maize production. Plant disease, 83(10), pp.884-895

Wegary, D., Abebe, F., Wolde, L. and Keneni, G., 2001. Grey leaf spot disease: a potential threat to maize production in Ethiopia. Sebil (Ethiopia).

Wegary, D., Kitaw, D. and Demissie, G., 2004. Assessment of losses in yield and yield components of maize varieties due to grey leaf spot.Pest Management Journal of Ethiopia (Ethiopia).

Wegary, D., Zelleke, H., Abakemal, D., Hussien, T. and Singh, H., 2008. The combining ability of maize inbred lines for grain yield and reaction to grey leaf spot disease. East African Journal of Sciences, 2(2), pp.135-145.

Wheeler BEJ (1969). An Introduction to Plant Diseases, John Wiley and Sons Limited, London p: 301.

Wolf, E.D. 2002. Field crop disease facts. Grey leaf spot. College of Agricultural and cooperative extension, PENN STATE. 